\title{
Further Studies on the Water Relations of Xerophilic Fungi, Including Some Halophiles
}

\author{
By S. ANDREWS ${ }^{1 *}$ AND J. I. PITT ${ }^{2}$ \\ 'School of Chemical Technology, South Australian Institute of Technology, Ingle Farm, SA 5098, \\ Australia \\ ${ }^{2}$ CSIRO Division of Food Research, North Ryde, NSW 2113, Australia
}

(Received 28 May 1986; revised 6 August 1986)

\begin{abstract}
Germination and growth of six fungi, Basipetospora halophila, Polypaecilum pisce, Aspergillus penicilloides, $A$. wentii, Eurotium repens and Exophiala werneckii, isolated from salt fish, and two new undescribed species from other sources, a Geomyces sp. and a Eurotium sp., were examined on media in which water activity $\left(a_{\mathrm{w}}\right)$ was controlled over a wide range by glucose/fructose, glycerol or $\mathrm{NaCl}$. Three species, $B$. halophila, $P$. pisce and Ex. werneckii, grew more rapidly on media containing $\mathrm{NaCl}$ in comparison with glucose/fructose, and hence can be considered to be halophilic. Two other species, $A$. penicilloides and $A$. wentii, were also unusually tolerant of $\mathrm{NaCl}: A$. penicilloides could grow on media saturated with $\mathrm{NaCl}$, while $A$. wentii grew more rapidly on $\mathrm{NaCl}$-based media down to $0.82 a_{\mathrm{w}}$ than any other xerophile examined so far. In contrast, the Geomyces sp. was intolerant of salt. The Eurotium sp. was obligately xerophilic, with growth confined to the range $0.935-0.68 a_{\mathrm{w}}$.
\end{abstract}

\section{INTRODUCTION}

Xerophilic fungi were defined by Pitt (1975) as those capable of growth under at least one set of environmental conditions at a water activity $\left(a_{\mathrm{w}}\right)$ below 0.85. Among xerophiles for which solute tolerances have been defined (Pitt, 1975; Pitt \& Hocking, 1977, 1982; Hocking \& Pitt, 1979; Luard \& Griffin, 1981) germination and growth were either not influenced by solutes or growth was more vigorous on media containing high concentrations of sugars rather than polyols or $\mathrm{NaCl}$. This paper describes the physiological characterization of some further xerophiles, particularly species isolated from salt fish, which might be expected to possess quite different solute tolerances. Two newly isolated and undescribed putative xerophiles from other sources were also included.

\section{METHODS}

Fungi. Eight xerophilic fungi were studied: Basipetospora halophila FRR 2608, from Japanese dried fish, 1984, FRR 2187, from imported Asian dried fish, 1979; Exophiala werneckii FRR 2561, from salted fish, 1980; Polypaecilum pisce FRR 2606, Aspergillus penicilloides FRR 2612, Aspergillus wentii FRR 2624, Eurotium repens FRR 2625, all from Indonesian dried fish, 1983; Geomyces sp. FRR 2375, from layer pellets, 1983; Eurotium sp. FRR 2471, from cardamom seeds, 1982. FRR denotes the culture collection of the CSIRO Division of Food Research, North Ryde, NSW, Australia.

Media. Media were prepared with water activities ranging from 0.997 to $0.747 a_{w}(\mathrm{NaCl})$ and $0.645 a_{k}$ (glucose/fructose, glycerol), in increments of approximately $0.02 a_{w}$, by adding $\mathrm{NaCl}$, glycerol or a mixture of equal weights of glucose and fructose to a basal medium as described by Pitt \& Hocking (1977). Media with water activities above 0.92 were sterilized by $15 \mathrm{~min}$ in steam at $100{ }^{\circ} \mathrm{C}$ on three successive days, the remainder by a single steam treatment. Actual $a_{\mathrm{w}}$ values of media were checked at the time of pouring into Petri slides with a SinaScope instrument (Sina, Zürich, Switzerland) calibrated using saturated salt solutions, ranging from $a_{\mathrm{w}} 0.643$ to $a_{\mathrm{w}}$ 0.980 (Robinson \& Stokes, 1955). 
Growth and observation of fungi. Inoculation and examination of fungal germination and growth were as described by Pitt $\&$ Hocking (1977). Incubation was at $25^{\circ} \mathrm{C}$ for a maximum of $100 \mathrm{~d}$.

\section{RESULTS \\ Germination}

Representative data for germination times of the fungi studied are shown in Fig. 1, in which $\log$ reciprocal germination times are plotted against water activity. Data for three fungi, $B$. halophila FRR 2608, $P$. pisce and Eurotium sp. FRR 2471 are shown in detail, as germination times on the three solutes were obviously different. For the other fungi, data are shown for only one solute, as solute type did not markedly affect germination time over most of the $a_{\mathrm{w}}$ range studied.

The minimum $a_{\mathrm{w}}$ values for germination of all the fungi on media containing the three different solutes are summarized in Table 1 . All of the fungi germinated at the highest $a_{\mathrm{w}}$ tested $(0.997)$ except Eurotium sp. FRR 2471, which failed to germinate on any solute above $0.935 a_{\mathrm{w}}$. Germination times for most of the fungi were shortest on the high $a_{\mathrm{w}}$ media $(0.997-0.970)$; however, germination of $B$. halophila occurred most rapidly between 0.95 and $0.90 a_{w}$, with an optimum at $0.91 a_{\mathrm{w}}$ on $\mathrm{NaCl}$ media. The optimum $a_{\mathrm{w}}$ for germination of Eurotium sp. FRR 2471 was very low, approximately 0.88 . Five of the fungi germinated on the medium containing saturated $\mathrm{NaCl}\left(a_{\mathrm{w}}, 0.747\right)$. B. halophila germinated within $6 \mathrm{~d}$ at $25^{\circ} \mathrm{C}$, but germination of Geomyces sp. took $90 \mathrm{~d}$ (Table 1). Spores of E. repens and $P$. pisce were the least tolerant of high $\mathrm{NaCl}$ concentrations and failed to germinate on salt media below $0.83 a_{\mathrm{w}}$.

\section{Radial growth rates}

Radial growth rates of seven of the fungi are shown in Fig. 2. Data for $E$. repens are not shown as they were qualitatively similar to those of E. chevalieri as reported by Pitt \& Hocking (1977).

The effects of solute on growth were generally similar to those on germination, although more pronounced. The effect of solute on $A$, wentii and $A$. penicilloides was minimal (Fig. $2 a$ ). $P$. pisce grew more rapidly on $\mathrm{NaCl}$ than on glycerol at high $a_{\mathrm{w}}$, and more rapidly on $\mathrm{NaCl}$ than on glucose/fructose over the entire $a_{w}$ range studied, especially below $0.90 a_{w}$ (Fig. $2 b$ ). Ex. werneckii showed faster growth on salt media, especially below $0.90 a_{\mathrm{w}}$.

The most pronounced solute effects were shown by the remaining fungi. Geomyces sp. FRR 2375 was intolerant of $\mathrm{NaCl}$ (Fig. 2c), while B. halophila exhibited much more rapid growth on $\mathrm{NaCl}$ media than in the presence of the other solutes (Fig. $2 d$ ). Germination of Eurotium sp. FRR 2471 was restricted to below $0.936 a_{\mathrm{w}}$; growth from inocula other than spores, at higher values, has not been tested. This fungus was the most xerophilic studied, growing

Table 1. Minimum $a_{\mathrm{w}}$ for germination and corresponding germination times for eight xerophilic fungi

\begin{tabular}{|c|c|c|c|c|c|c|}
\hline Solute & \multicolumn{2}{|c|}{$\mathrm{NaCl}$} & \multicolumn{2}{|c|}{ Glycerol } & \multicolumn{2}{|c|}{ Glucose/fructose } \\
\hline Fungus & Min. $a_{\mathrm{w}}$ & $\begin{array}{l}\text { Germination } \\
\text { time (d) }\end{array}$ & Min. $a_{\mathrm{w}}$ & $\begin{array}{l}\text { Germination } \\
\text { time (d) }\end{array}$ & Min. $a_{w}$ & $\begin{array}{l}\text { Germination } \\
\text { time (d) }\end{array}$ \\
\hline B. halophila & 0.747 & 5.8 & 0.780 & $8 \cdot 1$ & 0.770 & 14 \\
\hline P. pisce & 0.831 & $7 \cdot 5$ & $0.749^{*}$ & $7 \cdot 1$ & $0.770^{*}$ & 3.9 \\
\hline Ex. werneckii & 0.747 & 25 & 0.780 & 25 & 0.770 & 15 \\
\hline E. repens & 0.831 & 1.8 & 0.721 & 18 & $0.685^{*}$ & 85 \\
\hline A. wentii & 0.791 & 6.7 & $0.749^{*}$ & 28 & 0.734 & 21 \\
\hline A. penicilloides & 0.747 & $8 \cdot 3$ & $0.734^{*}$ & 14 & 0.770 & 5.8 \\
\hline Geomyces sp. & $0.747^{*}$ & 90 & $0.749^{*}$ & 38 & $0.734^{*}$ & 90 \\
\hline Eurotium sp. & 0.747 & 32 & 0.721 & 44 & 0.675 & 38 \\
\hline
\end{tabular}

* Although germination occurred at this $a_{\mathrm{w}}$, the formation of at least microcolonies did not follow. 


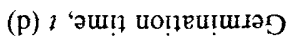

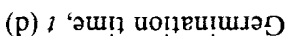
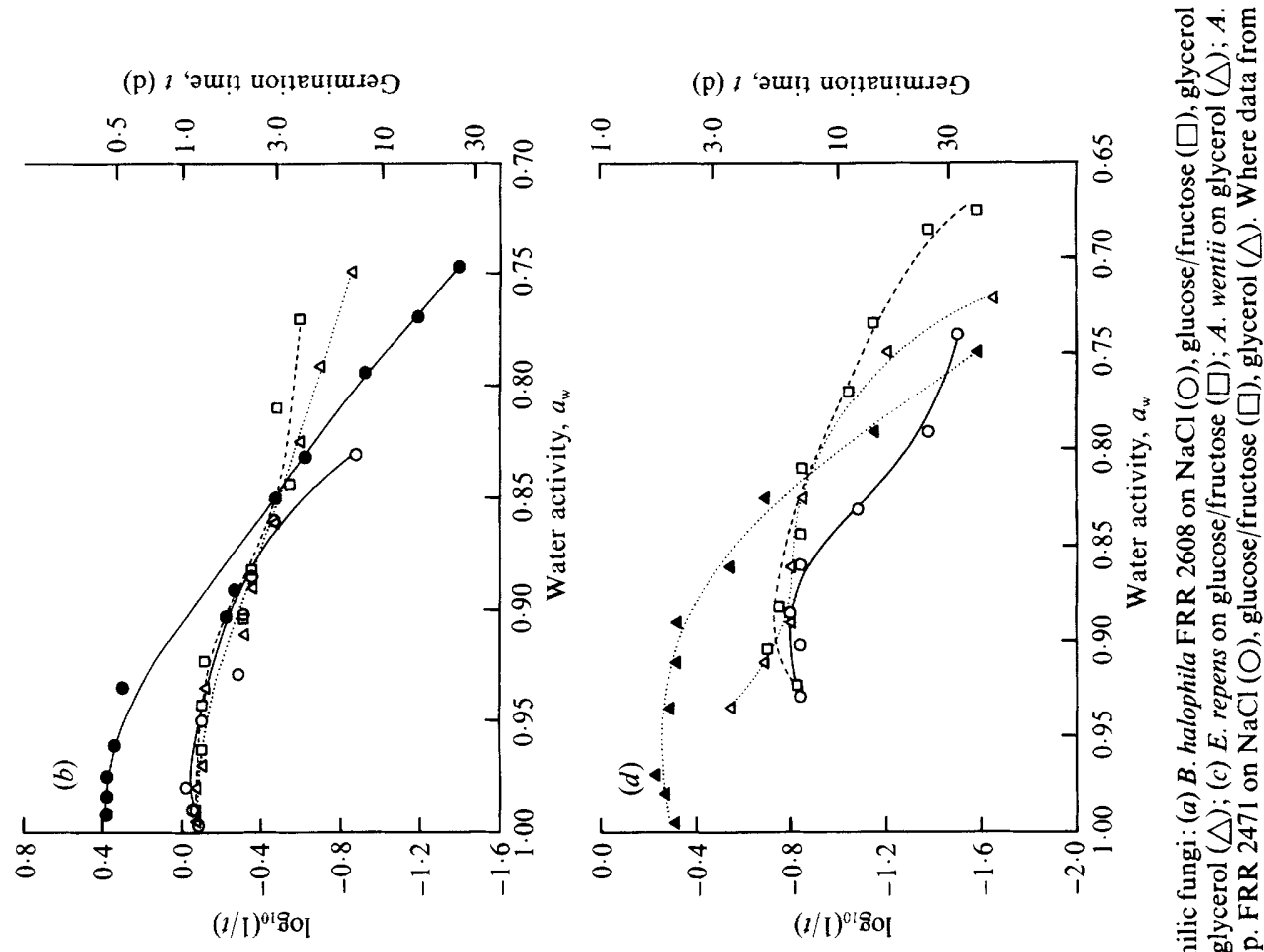

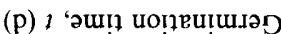

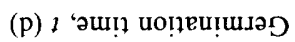

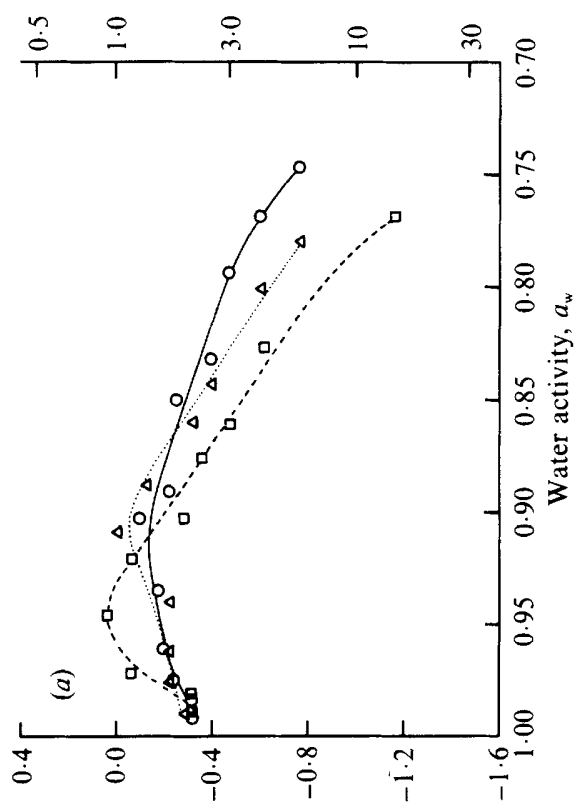

$(1 / 1)^{01801 ~}$

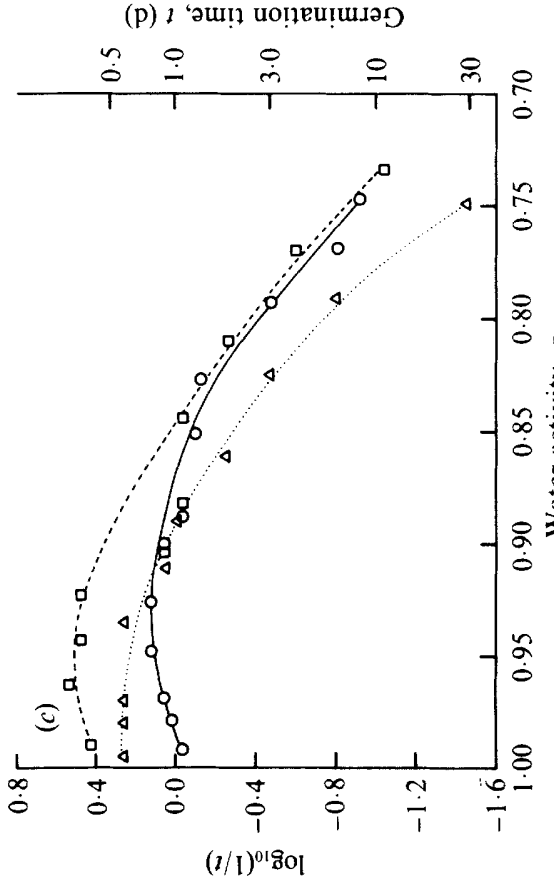

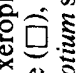

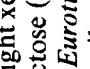

ए

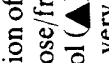

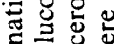

Eิ

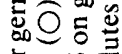

웜 $\frac{n}{2}$

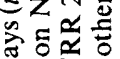

인

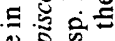

हैं है

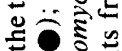

동

过

등ํㅇํㅇ

을 :

उ 屯ัँ

ㅇํํ

进通完

- - 응

䗆藏 

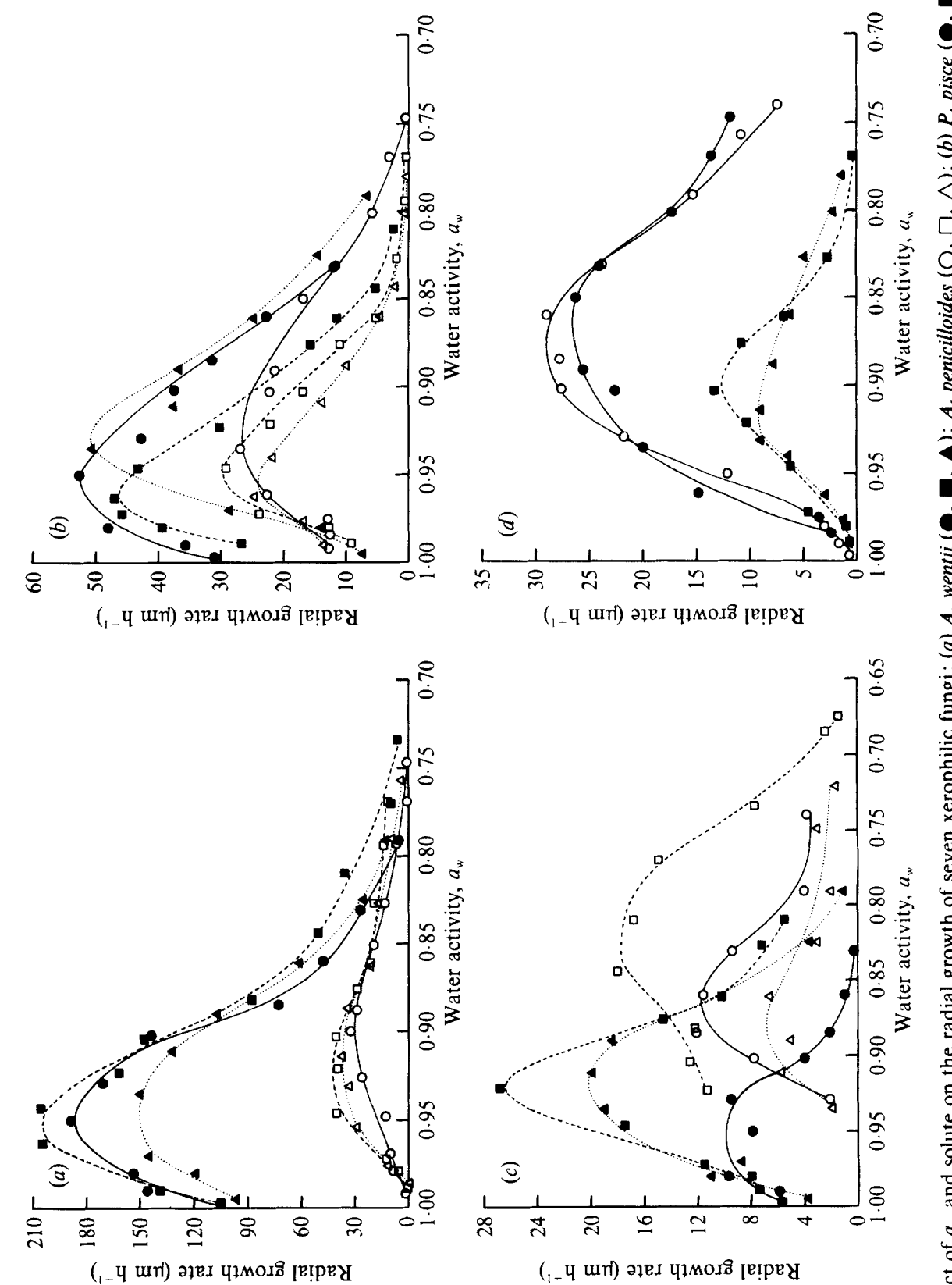

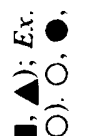

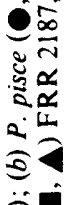

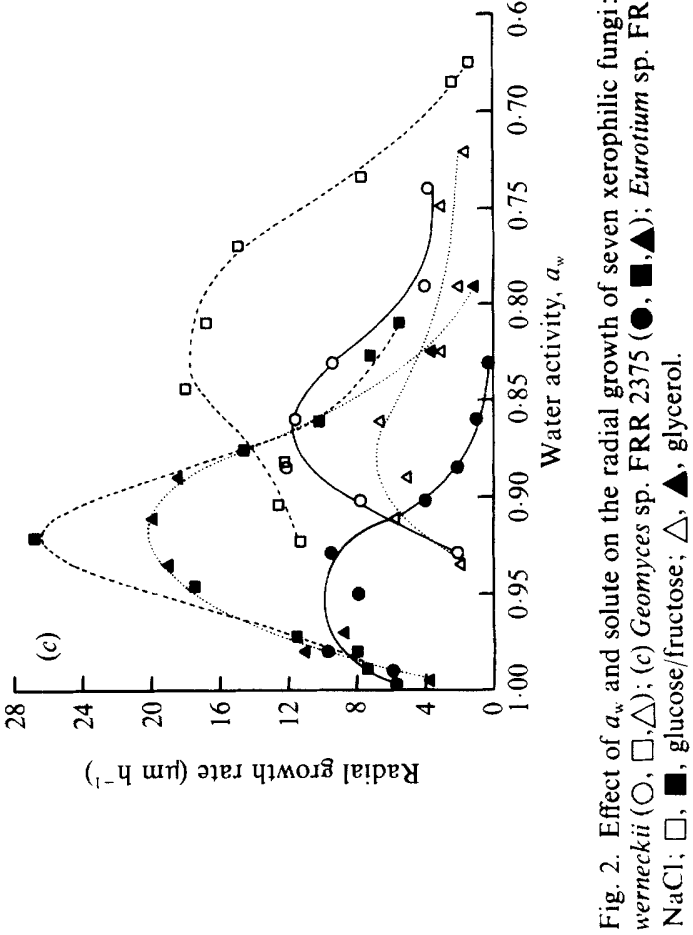


optimally at $0.88-0.84 a_{\mathrm{w}}$, and as low as $0.68 a_{\mathrm{w}}$. Growth was markedly more rapid on glucose/fructose than on the other media. The other fungi studied grew at or near $0.997 a_{\mathrm{w}}$, although growth of $A$. penicilloides and $B$. halophila was very slow at the higher water activities.

In general the minimum $a_{\mathrm{w}}$ for growth on the three solutes was the same as the minimum $a_{\mathrm{w}}$ for germination. In a few cases, where germination times were long, growth did not occur within the time limits of the experiment. Such cases are indicated in Table 1. The minimum recorded $a_{\mathrm{w}}$ for growth of both $P$. pisce and Geomyces sp. FRR 2375 was 0.79 .

The optimal $a_{\mathrm{w}}$ values for growth of the fungi examined were as follows: $A$. wentii, 0.96-0.94; P. pisce, 0.96-0.94; Ex. werneckii, 0.96-0.93; Geomyces sp. FRR 2375, 0.95-0.92; E. repens, 0.95$0.91 ;$ A. penicilloides $0.93-0.90 ; B$. halophila, 0.89-0.86; and Eurotium sp. FRR 2471, 0.88-0.84.

\section{DISCUSSION}

Pitt (1975) discussed the status of fungi which had been claimed to exhibit enhanced growth in $\mathrm{NaCl}$ solutions, i.e. were considered to be halophilic, and concluded that there was no evidence for halophilism in fungi. However, the experiments reported here demonstrate both the superior growth of $B$. halophila in media with $\mathrm{NaCl}$ as the major solute (Fig. $2 d$ ), and the ability to grow in media saturated with $\mathrm{NaCl}$. Clearly, $B$. halophila is a halophilic fungus. In contrast with obligately halophilic bacteria, but in common with facultatively halophilic bacteria and the alga Dunaliella (Brown, 1976), growth of $B$. halophila is stimulated by $\mathrm{NaCl}$ but there is no obligate requirement. Two isolates of $B$. halophila from dried fish showed similar water relations, including enhanced growth in $\mathrm{NaCl}$. A third strain isolated from indigo solution has also been examined, and shared these properties (unpublished observations), indicating that this is a stable physiological characteristic of this species.

Our results also indicate that Ex. werneckii and $P$. pisce can be considered to be halophilic because of their superior growth on media containing $\mathrm{NaCl}$ compared with glucose/fructose below $0.90 a_{\mathrm{w}}$. Ex. werneckii was able to grow in the presence of saturated $\mathrm{NaCl}$, although slowly. $A$. penicilloides also grew on media saturated with salt, but grew equally well on other solutes.

Aspergillus and Eurotium species are generally less well adapted to growth in the presence of high $\mathrm{NaCl}$ concentrations, as previously reported for $A$. flavus, $A$. ochraceus and $E$. chevalieri (Pitt \& Hocking, 1977) and observed here for E. repens. The results reported here for $A$. wentii are noteworthy on three accounts: (1) the high growth rates on both $\mathrm{NaCl}$ - and glucose/fructosebased media near $0.95 a_{\mathrm{w}}$; (2) its strongly xerophilic nature, which exceeds that of most of the other frequently studied species of Aspergillus; and (3) its salt tolerance, as it exhibits the fastest growth of any fungus thus far studied on $\mathrm{NaCl}$-based media down to $0.82 a_{\mathrm{w}}$ at $25^{\circ} \mathrm{C}$. The latter two observations are unexpected, as Pitt \& Christian (1986) reported the minimum $a_{\mathrm{w}}$ for growth of $A$. wentii to be $0 \cdot 84$, and considered this species to be a xerophile of little consequence.

Pitt \& Hocking (1977) suggested that the less specialised xerophilic fungi such as Aspergillus species were little affected by solute type, but that more highly adapted fungi, such as Xeromyces bisporus and Chrysosporium fastidium, were more sensitive, particularly to $\mathrm{NaCl}$. The results of these studies confirm this. B. halophila, Eurotium sp. FRR 2471 and Geomyces sp. FRR 2375 can all be considered to be highly adapted xerophilic fungi. Like $X$. bisporus and $C$. fastidium, they have specialized growth requirements, and appear to have evolved to occupy specific ecological niches, $B$. halophila being successful in salt environments, while the others are adapted to highsugar environments.

Ex. werneckii is particularly interesting, because it is usually isolated as a human pathogen, i.e. from environments of very high $a_{\mathrm{w}}$. Adaptation to environments of low $a_{\mathrm{w}}$, as reported by Mok et al. (1981) and confirmed here, is surprising.

Previous studies with xerophiles indicated that glycerol was a satisfactory solute in media of reduced $a_{\mathrm{w}}$ for the isolation and enumeration of xerophiles (Pitt \& Hocking, 1977) and it was used as the basis of Dichloran $18 \%$ glycerol agar (DG18) (Hocking \& Pitt, 1980). This medium has been effective for the isolation and enumeration of most xerophiles from dried and concentrated foods. However, the results shown above indicate that the halophilic fungi studied here grow poorly on glycerol. In examining foods high in $\mathrm{NaCl}$ an alternative isolation medium, 
such as malt extract/yeast extract $/ 5 \%$ salt $/ 12 \%$ glucose agar (Pitt \& Hocking, 1985a), is recommended for the isolation of halophilic fungi (Pitt \& Hocking, 1985b).

\section{REFERENCES}

Brown, A. D. (1976). Microbial water stress. Bacteriological Reviews 40, 803-846.

Hocking, A. D. \& PITT, J. I. (1979). Water relations of some Penicillium species at $25^{\circ} \mathrm{C}$. Transactions of the British Mycological Society 73, 141-145.

Hocking, A. D. \& PITT, J. I. (1980). Dichloranglycerol medium for enumeration of xerophilic fungi from low-moisture foods. Applied and Environmental Microbiology 39, 488-492.

LUARD, E. J. \& GRIFFIN, D. M. (1981). Effect of water potential on fungal growth and turgor. Transactions of the British Mycological Society 76, 33-40.

Mok, W. Y., Castelo, F. P. \& Barreto, de Silva, M. S. (1981). Occurrence of Exophiala werneckii on salted freshwater fish Osteoglossum bicirrhosum. Journal of Food Technology 16, 505-512.

PITT, J. I. (19/5). Xerophilic fungi and the spoilage of foods of plant origin. In Water Relations of Foods, pp. 273-307. Edited by R. B. Duckworth. London: Academic Press.
PiTT, J. I. \& ChRistian, J. H. B. (1968). Water relations of xerophilic fungi isolated from prunes. Applied Microbiology 16, 1853-1858.

PITT, J. I. \& Hocking, A. D. (1977). Influence of solute and hydrogen ion concentration on the water relations of some xerophilic fungi. Journal of General Microbiology 101, 35-40.

PITT, J. I. \& Hocking, A. D. (1982). Food spoilage fungi. I. Xeromyces bisporus Fraser. CSIRO Food Research Quarterly 42, 1-6.

PItT, J. I. \& Hocking, A. D. (1985a). New species of fungi from Indonesian dried fish, Mycotaxon 22, 197-208.

PITT, J. I. \& Hocking, A. D. (1985b). Fungi and Food Spoilage. Sydney: Academic Press.

Robinson, R. A. \& STOKES, R. H. (1955). Electrolyte Solutions. New York: Academic Press. 